\title{
"I'M NOT AFRAID OF BEING CALLED A LOSER": THE ISSUE OF AGENCY IN FINN'S IDENTITY CONSTRUCTION IN THE TELEVISION SERIES GLEE
}

\author{
Leonardo da Silva ${ }^{1}$
}

\begin{abstract}
This article analyzes the television series Glee and discusses the ways in which Finn's identity construction - and his irresolution - can be read counter-hegemonically as fostering political agency. In order to do so, I discuss the concepts of identity and agency and notions such as social location and identification while conducting a textual analysis of specific scenes that pertain to the first season of the series. The analysis highlights that the character's experience with the Glee club seems to be important for the constant re-construction of his identity. Such reconstruction is always part of a double movement: Finn, as a postmodern subject, is overtly contradictory. While his identity construction can be considered transgressive, at times his actions are in fact very conservative. Finn's identity construction seems to demonstrate the ways in which Glee can be considered an example of postmodern contingency while being inserted simultaneously within restraining hegemonic discourse.
\end{abstract}

Keywords: Identity. Agency. Television series Glee. Postmodern subject.

\section{"NÃO TENHO MEDO DE SER CONSIDERADO UM PERDEDOR": A QUESTÃO DA AGÊNCIA NA CONSTRUÇÃO IDENTITÁRIA DE FINN NA SÉRIE DE TELEVISÃO GLEE}

\begin{abstract}
Resumo: Este artigo analisa a série de televisão Glee e discute como a construção identitária do personagem Finn - e sua irresolução - pode ser lida contra hegemonicamente de forma a promover agência política. Para tanto, discuto os conceitos de identidade e agência e noções como local social e identificação ao conduzir uma análise textual de cenas da primeira temporada da série. A análise destaca que a experiência do personagem com o clube Glee parece ser importante para a constante reconstrução de sua identidade. Esta reconstrução é sempre parte de um movimento duplo: Finn, como um sujeito pós-moderno, é contraditório. Enquanto sua identidade pode ser vista como transgressiva, em alguns momentos suas ações são na verdade bastante conservadoras. A construção identitária de Finn parece demonstrar como a
\end{abstract}

${ }^{1}$ Instituto Federal de Santa Catarina (IFSC). E-mail: leonardo.silva@ifsc.edu.br. 
série Glee pode ser considerada um exemplo de contingência pós-moderna ao mesmo tempo em que está inserida no discurso hegemônico.

Palavras-chave: Identidade. Agência. Série televisiva Glee. Sujeito pósmoderno.

\section{Introduction}

A story about high school teenagers struggling to define themselves in a competitive and unfair environment does not seem to bring anything new to American television narratives. Ryan Murphy's Glee $^{2}$ (2009-2015), however, differentiates itself because it centers around a group of so-called losers, that is, teenagers who do not meet the social standards (in terms of beauty, gender, sexuality, ableism and so on) that are constantly reinforced in and by the educational system. These young people can be considered "outsiders" who are often bullied and discriminated against in the school system. Since the main characters in the television series are constructed as outcasts, one may be surprised while observing that Finn Hudson (one of the members of the Glee club) is - at least in the beginning of the narrative - a popular football player. The quarterback in the football team, Finn is the stereotypical popular boy white, athletic, and masculine. However, even though he is not considered a "loser" like the other kids, he ends up joining the singing club in the pilot episode of the series. Even with the risk of changing his status of a "popular guy", he steps out of the comfort zone and becomes a member of both the singing club and the football school team. This decision is considered contradictory not only by his peers, but also by his football coach.

Bearing this in mind, this article discusses how Finn's identity construction - and his irresolution - can be read counter-hegemonically as fostering political agency ${ }^{3}$. To do so, I discuss the concepts of identity

${ }^{2}$ Glee is a US - North American television series created by Ryan Murphy for Fox channel. It was aired between 2005 and 2015 and had a total of six seasons.

${ }^{3}$ This article presents some of the results of the author's unpublished Master's thesis. For more on the topic, see Silva (2014). 
and agency and notions such as social location and identification while conducting a textual analysis of specific scenes that pertain to the first season of the series.

\section{Identity and agency}

Identity, from a Cultural Studies perspective, is always subjected to change. According to Jen Webb (2009, p. 65), an individual's identity is a tenuous thing: identity is not something that humans are born with, but something that is developed and that could even be lost. Kimberle Crenshaw (1991, p. 1243) postulates that in order to understand oppression it is necessary to look at identity from an intersectional perspective. For her, it is not possible to understand how black women are oppressed, for instance, by simply looking at one specific identity category. Instead, we should consider how different identity categories (race, class, gender, and so on) are interrelated and intersected.

Butler (1999, p. 182) explains that our identities are defined in relation to society's constraints; that is, we can only define ourselves within a limited set of possibilities. At the same time, however, Butler (1999, p. 182) emphasizes that, despite society's constraints, there is always room for agency: "if the subject is culturally constructed, it is nevertheless vested with an agency, usually figured as the capacity for reflexive meditation, that remains intact regardless of its cultural embeddedness". In this sense, from a poststructuralist perspective agency is the ability to act upon our identities in relation to the discursive possibilities that are culturally available at each given moment. Expanding on Foucault's notion of poststructuralist agency towards its implications on gender, Butler (1999, p. 182) makes it clear, then, that "[o]n such a model, 'culture' and 'discourse' mire the subject, but do not constitute the subject". Since our identities are constructed through performativity (which has to be constantly reinforced through repetition), "the ideal is never accomplished, it must always be attempted again" (LOXLEY, 2006, p. 124). Agency may arise in this context because the "focus on repetition further permits the suggestion that the norms thus repeated and recited themselves become vulnerable in their repetition". After all, they are 
not "a law that we are simply condemned to obey; [...] and the spell could be broken" (LOXLEY, 2006, p. 124).

\section{Irresolution as agency}

In the pilot episode of Glee, the teacher, Will Schuester, after distributing sign-up sheets for the singing club, decides to talk to the football team members about the auditions. His purpose is to find more members for the choir, which has only a few students. His attempts seem to be unsuccessful, since no one takes his proposal seriously. Later, however, Will hears a student singing "I can't fight this feeling" while taking a shower. The boy singing is Finn and he has a beautiful voice. However, Will is aware that Finn would not join the Glee club because of his peers' and his own prejudice against the arts. It is interesting to notice that the lyrics sung by Finn are about a man falling in love with a girl that he has been friends with, which seems to foreshadow Finn's future relationship with Rachel Berry in the narrative. At the same time, the lines "I can't fight this feeling any longer / And yet I'm still afraid to let it flow" are ambiguous, for they can also be understood metaphorically as referring to Finn's initial fear of admitting that he likes singing and of joining the Glee club. At last, this scene can be considered very homoerotic if we consider that Finn only sings in the closeted space of the shower and that Will acts as a kind of voyeur who discovers his talent.

At first, power is used by Will in order to convince Finn to take part in the club. At this point, Finn still does not want to join the choir - in a way, he is forced to do so. Will blackmails Finn by accusing him that marijuana was found in his locker. The teacher then tells him that he will denounce him unless he joins the choir. Because of Will's blackmailing, Finn reflects about his life. Through his voice-over narration, the viewer learns about his thoughts and his past: after his father died in the war, he felt like he should make "his mom proud" by being an honorable man and son. As a consequence, he decides that it is better to join the Glee club than being accused of possessing drugs, since the latter could harm his possibility of obtaining a scholarship from a renowned university. 
Power is abused once again when Finn's coach tells him to choose between joining the Glee club or the football team. Finn, trying to find a solution, hides the fact that he is part of the choir. His friends from the football team end up discovering the truth, though. They do not understand why he is part of the "flag team", as Puckerman, one of the football players, puts it.

Interestingly enough, Finn realizes that his friends from the football team have different values when they bully Artie, a disabled boy who is also a choir member. Disagreeing with their actions, Finn helps Artie and takes him out of the portable toilet where his friends had locked him. That is when Puckerman asks him why "he is helping out a loser". Finn's reply is revealing:

Don't you get it, man? We're all losers. Everyone in this school [...] I'm not afraid of being called a loser because I can accept that's what I am. But I am afraid of turning my back on something that actually made me happy for the first time in my sorry life (MURPHY, 2009).

This discourse is indeed problematic if we consider that Finn endorses the meaning of "loser" as defined by an ableist hierarchy which lays blame for exclusion on the person excluded rather than on the systematic asymmetries of access. At the same time, this is the first moment in which Finn acknowledges his will to join the Glee club. Puckerman asks him, then, if he is going to quit the football team to join "homo explosion”. Finn answers: “No. I'm doing both. 'Cause you can't win without me and neither can they". Then, Finn becomes a kind of a leader to the Glee club, assigning roles and motivating the other members to continue rehearsing although the teacher will no longer (at least at this point in the narrative) be able to help them.

In this context, I argue that Finn decides to defy society's norms by becoming an "in-between". He does not conform to the simplistic definitions of "popular/loser", and his decision to not define himself as solely one or the other, that is, his irresolution, represents a possibility for agency. Even though the term irresolution commonly refers to the 
indecision on how to act, in this case it works in the opposite direction: it is the character's irresolution in defining himself according to society's labels that promotes his agency in terms of identity. He acts upon his identity on a conscious level and, despite the consequences that he has to face - since he may become marginalized in the school context - he maintains his position as an in-between. For Homi Bhabha (1994, p. 2), it is exactly these in-between spaces that "provide the terrain for elaborating strategies of selfhood - singular or communal - that initiate new signs of identity, and innovative sites of collaboration, and contestation, in the act of defining the idea of society itself". It is in this sense that I claim that Finn's identity can be considered queer. His "in-betweeness" serves as a way of contesting society's norms and, therefore, allows for different meanings in terms of identity to be constructed.

It is meaningful, therefore, that Finn's deferral of decision (at least when it comes to choosing one of the poles) may be understood as a political act. In acknowledging that he is going to be part of both groups, he is making the claim that the articulation between two poles of what has always been considered opposite (that is, the popular versus the loser) is possible. Not only does he understand the difficulties that the "outcasts" face in the school environment, but he also names himself as one of them. He resignifies "loss" through the refusal of a dominant hierarchy and its privileges - he is also a "loser", and his privileged position as a "popular football player" serves as a way of struggling against the school's oppressive system. As Gurpreet Singh Johal (2005, p. 287) explains, “[o]ne cannot simply acknowledge one's privilege and continue to do what one has always done. Action is the only way to measure the commitment of the privileged in the attempt to denaturalize their position". In this sense, Finn is aware of his importance in the two groups, since he even affirms that both need him in order to win.

Not only does Finn acknowledge his importance in the club, but he also realizes the importance that singing has for himself. In this way, Glee serves as an opportunity of self-discovery for him. Moreover, throughout the different episodes, some of the songs he chooses to perform are representative of his own queer and fluid identity, thus 
allowing the viewers to learn more about him through the lyrics. As Gelles (2011, p. 94) explains, the songs featured in the show usually reflect themes regarding each character's identity or in relation to the narrative as a whole. At the end of the pilot episode, for instance, the members of the Glee club perform the song “Don't stop believin'. Finn is the male lead singer in the presentation, and the song, which becomes an anthem for the television series, seems to provide a hopeful message for the singing club. Despite all the difficulties, they will continue "believing" in themselves and, because of that, they will not give up being part of the choir.

\section{Critical political agency: identity, social location and identification}

Finn's irresolution can be seen as evidence that our identities are not fully constituted by the systems of representation that constantly interpellate us. Even though he faces peer pressure and is stigmatized by many other students, he does not let them decide who he is or what he will do. At times, he considers leaving the Glee club, but he always ends up deciding to remain in the group. Finn's decision seems to be closely aligned with the concept of political agency. For Rosaura Sánchez (2006, p. 33), who discusses identity from a critical realist perspective, "a critical politics of identity can play a part in political organizing and in challenging hegemonic discourses". She explains that, even though we are always situated "within specific social structures (be they economic, political or cultural)", our identities are not reduced to these locations. Besides, these structures are in constant transformation, so our locations are not fixed either.

In the case of the Glee club, for instance, the characters are located, in terms of class, in a public high school, which depends on investments and funds in order to exist. The situation is even more critical if we consider that, in the school environment, the arts (such as singing and performing, as in the case of Glee) are not valued. Throughout the entire first season, the characters worry that Glee may end because of the lack of support from the school. Because of that, they need to succeed in the regional and sectional competitions in order to continue having a 
place to rehearse at school. In this sense, it seems that, if we consider this specific location, there seems to be little room for change or emancipation. However, as Sánchez (2006, p. 35) explains, identity “cannot be reduced to social location or positioning, but it cannot be analyzed in any meaningful way without taking it into account".

This realist view of identity is directly related to the concept of agency. As Linda Martín Alcoff and Satya P. Mohanty (2006, p. 6) explain, for the realist theory of identity "[s]ocial identities can be mired in distorted ideologies, but they can also be the lenses through which we learn to view our world accurately". In this view, identities are not simply imposed on us - rather, we can also "create positive and meaningful identities that enable us to better understand and negotiate the social world" (ALCOFF and MOHANTY, 2006, p. 6). In other words, it is possible to rearticulate or to act - performatively - upon those structures that surround us in order to promote meanings that can better account for our identities' complexities.

Another important concept for understanding identity formation is that of identification, which "designates individuals as part of a whole" (ALCOFF AND MOHANTY, 2006, p. 40). This identification does not necessarily come from the subject: such is the case of Finn, who at first joined the Glee club as a result of having been blackmailed by his teacher. At the same time, he was not considered a loser until the school community recognized him as one. It was only after being discriminated against that he embraced the label. Based on that, it is possible to say that identification "is a discursive process that can serve to signal a group's isolation, uniqueness, segregation, rejection, subordination, domination, or difference vis-à-vis others" (ALCOFF AND MOHANTY, 2006, p. 40). In this sense, the term "loser" is used by the community in order to stigmatize the members of the Glee club. Nevertheless, it is also appropriated by the Glee members themselves. Finn, for instance, recognizes that he is indeed a loser, but highlights that this should not prevent him from doing what he likes. In this way, he re-signifies the term by thus contextualizing it as no longer pejorative. 
In The Queer Art of Failure, Judith Halberstam (2011, p. 2) argues that the notions of success and failure help reinforce "specific forms of reproductive maturity with wealth accumulation". In this sense, the idea that one needs to succeed, win, or even be popular is part of the capitalist logic which, as she argues, helps to sustain heteronormativity. To move away from these capitalist and heteronormative understandings of society, the author proposes a dismantling of these logics: "[u]nder some circumstances failing, losing, forgetting, unmaking, undoing, unbecoming, not knowing may in fact offer more creative, more cooperative, more surprising ways of being in the world" (HALBERSTAM, 2011, p. 2-3). As I intend to make clear, it is exactly by being a Glee member - and, therefore, a so-called loser - that Finn can come up with other forms of being that can better reflect his fluid identity.

Similarly, the show Glee has been advertised as "a biting comedy for the underdog in all of us". In this sense, in many posters that promote the series it is possible to see one of the main characters making a hand gesture by extending the thumb and index fingers, resembling an "L". Not only does this gesture serve as a way of forming the words "Glee" and "loser", but it also works as a form of identification. The characters themselves do not reproduce this hand gesture in the episodes, but it has served as a way of identifying the series and its fans. In this context, the concept of "loser" is no longer negative. This strategy can be compared to the one of using the term queer, which served at first as a form of discrimination against those who did not conform to heteronormativity. Nowadays, however, the term has been re-appropriated and re-signified, and has even been used to identify a field of study concerned with the limits and instability of identity.

Bearing in mind Finn's social location and identification as a Glee member who resignifies the term "loser", it is possible to understand how his identity formation can be understood as fostering critical political agency. Finn's in-between position is what allows him to rearticulate his identity so as to develop agency. As Sánchez (2006, p. 41) explains, "identity is always agential". It also implies "reflexivity, a willing connection to a collectivity, and a recognition of being bound to a group" 
(SÁNCHEZ, 2006, p. 41). In this sense, Finn's identity construction can be understood as a form of mediation "between the individual and the world" (SÁNCHEZ, 2006, p. 42). As Susan Stanford Friedman (online, n.p.) points out, identity can be understood as a constant interplay "between agency on the one hand and on the other hand, overdetermination by material and ideological conditions". Besides, "[i]ndividuals belong to multiple communities - sometimes overlapping, sometimes contradictory" (FRIEDMAN, online, n.p.), as in the case of Finn.

\section{"I see a future where it's cool to be in Glee club"}

Despite the fact that Finn resignifies the term "loser" by embracing it and being part of the Glee club, his peers at school continue discriminating against him. This can be exemplified by the first scene of the episode entitled "Mash-up", in which the camera follows the image of a hand carrying a slush, that is, a flavored frozen beverage. The slush is very significant in the narrative in the sense that it is used as a tool of bullying against the so-called losers. These beverages are thrown at their faces as a form of humiliation for being "different". In this specific scene, the slush that the camera focuses on is thrown at Finn, who is no longer seen as a popular guy at school.

In the same episode, the teacher decides that the theme for the performances in that week would be "mash-ups". He explains that mashups - that is, the combination of two or more songs into one - exemplify that things that seem to be so different can actually be together. In his own words, "the difference between them is what makes them great". This can be understood not only as referring to the songs and performances themselves, but also to the characters' and, more specifically, to Finn's position. After all, in the same scene Finn even mentions the "combination" of Glee club and football as an example of Will's point.

However, Finn is bullied not only for being in Glee, but also because he is believed to be the father of Quinn's baby. Quinn is also a member of the club who, after gaining some weight during her pregnancy, is expelled from the school cheerleading team. Her status also changes - 
due to her teenage pregnancy and her participation in Glee, she is also labeled as a "loser". Finn is not the father of her child, but since his character is sometimes constructed as "innocent" or even "dumb" (Quinn even refers to him as possessing a "pea-brain"), he believes Quinn when she tells him that she got pregnant by only being together with him in a bathtub.

This characterization of Finn as being "dumb" is important in the sense that it seems to go against the transgressive project that, as I have been trying to show, is part of the series. By referring to Finn as a "peabrain", Quinn is emphasizing the image of the stereotypical football player, who is strong and into sports, but is never smart. I believe, however, that the very same stereotype can be questioned through Finn's agency. He is smart enough, for instance, to be critical in relation to society's norms and question his own position in the school environment.

In this sense, different reasons contribute to how Finn is discriminated against: not only is he part of Glee, but he is also believed to be partially responsible for a teenage pregnancy. After throwing the slush at Finn, for instance, Karofsky - who is part of the school hockey team says: "Now that you've joined Lullaby Lee's and imperminated the queen of the Chastity Ball and dropped below us hockey dudes on the food chain? It's open season". At first, it is interesting to notice that the two teenagers, affected by the bullying, decide that they want to be popular again. Because of that, they look for advice on how to be cool. Emma, the school counselor, reminds them that they should be whoever they are: "and if people don't like you for that, then I'm sorry... but who needs them?" At this point, it is possible to observe a change in Finn's attitude - as a teenager, he wants to belong to the school community so as not to suffer prejudice.

Finn is also pressured by his football peers, who start questioning his leadership skills. According to them, because Finn may be "having trouble making good choices" (such as deciding to be part of Glee), he may not be the right person to guide the team. At the same time, other dynamics of power influence Finn's difficult positioning. The football coach, for example, tells him to choose what he considers more important 
- football or Glee. He only requires Finn to do so, however, because he is not happy with the relationship Will Schuester (Glee's coach) has with his girlfriend. By making the boys choose between football and Glee, he may jeopardize the future of Glee and also affect Will's life. After all, the club only has the minimum number of participants in order to be eligible for the singing competitions and any downsize could prevent it from existing officially at school. In this sense, the club is inserted into a capitalist context of meritocracy, in which winning is almost a question of survival.

After the football coach's ultimatum, Finn does not show up for Glee club practice. All the other boys opt for Glee, but Finn decides to go to the football practice. Later, a scene that is very similar to the first one in the episode is shown - the camera follows a hand that holds a slush. This time Finn is the one holding the beverage that is probably going to be thrown at one of the "losers". This technique of repetition emphasizes the ways in which Finn is now considered the "Other's other". In the beginning of the episode, he was the otherized and attacked one. Now that he is no longer part of the singing club, he becomes the attacker. His attitude, however, is different: he explains that he cannot do that. Rachel says: “He's made his choice. He doesn't care about us losers anymore". Kurt, on the other hand, grabs Finn's drink and throws it at himself. Then, he explains: "It's called taking one for the team. Now get out of here. And take some time to think whether or not any of your friends on the football team would have done that for you". I would like to emphasize that the use of "you" instead of "us" in this context is relevant because it is an act that reinscribes hierarchy, since Kurt is establishing a clear division between the Glee club and Finn. Besides, it is also important to mention that these experiences with the Glee club members seem to be important for the constant re-construction of Finn's identity. Such reconstruction is, in my view, always part of a double movement: Finn, as a postmodern subject, is overtly contradictory. While his identity construction can be considered transgressive, at times his actions are in fact very conservative.

Will Schuester also has a conversation with Finn about his decision to join the football team. Will tells him that "life is a series of 
choices, a big combination of moments - little ones that add up to big ones that create who you are". In a way, Will's speech can be understood as highlighting that agency has an important role in defining our identities. He also complements his view by saying to Finn that he is letting other people make choices for him: "You're letting them decide who you're gonna be".

Finn's "loser" identity intersects with various layers of his identity which are sociohistorically privileged - it cannot be ignored, for instance, that he is white, male, straight, masculine, and enjoys middleclass access to education. Because he has occupied an in-between position - as a "loser" who could also be a "winner", one may argue that he is, to use Paula M. L. Moya's term, epistemically privileged. For Moya (2000, p. 8081), epistemic privilege "refers to a special advantage with respect to possessing or acquiring knowledge about how fundamental aspects of our society (such as race, class, gender, and sexuality) operate to sustain matrices of power". At the same time, however, she acknowledges that being oppressed does not guarantee this greater understanding of the power relations one is part of. In this sense, "an individual's identity will influence, but not entirely determine, the formation of her cultural identity" (MOYA, 2000, p. 82). For Moya, "identities both condition and are conditioned by the kinds of interpretations people give to the experiences they have" (2000, p. 83). In this sense, Finn is constantly in the process of re-interpreting his experiences, as in the case of quitting Glee club.

This is because, after reflecting about his choices - and after having had a conversation with Will -, Finn talks to his football coach. Once again, he seems to have made new sense of his experiences so as to decide to go back to Glee.

In this case, Finn seems to be in a position of epistemic privilege, since he begins to realize the ways in which the school environment excludes and discriminates students at various levels. Not only that, but he also assumes the position of an agent who makes conscious decisions based on the knowledge he has acquired from his experiences. This position of epistemic privilege is only possible because Finn questions society's norms. According to Moya (2000, p. 87), oppositional struggle is “a 
necessary (although not sufficient) step toward the achievement of an epistemically privileged position". At the same time, Finn's hope that in the future Glee can be considered "cool" can be seen as a way of perpetuating hegemony through the creation of new market niches. This is because this idea of inclusion is simplistic and often serves to oppress other others when intersections with race, class, ethnicity, gender or disability are ignored.

Finn's attitude ends up being very effective: the football coach cancels some of the team's practices, allowing its members to be part of the Glee club as well. At the end of the episode, the Glee members celebrate Finn's return with slushes, the exact same beverages that are also the symbol for the ways in which they are humiliated at school. All the Glee members throw their beverages at Will, the teacher. This time, however, this is not an act of humiliation. Rather, it is as if they were making a toast to Finn's return and celebrating the fact that all of them including their teacher - had something in common and were, therefore, together in the Glee club. It is important to acknowledge, however, that the narrative at the end of this episode can also be considered problematic in the sense that it is one of resolution and closure, as if everything could be easily and simply solved despite social structures.

\section{"I realize I still have a lot to learn"}

Since Finn is not epistemically privileged where his supposed "loser" identity intersects with other sociohistorically privileged layers of his identity, his actions are often conservative at least in the sense that they reinforce heteronormativity as well as the supremacy of masculinity. At times, he is strongly influenced by commonsensical ideas about gender - in the episode named "Theatricality", for instance, Finn discovers that he is going to move to Kurt's house. This is because his mother has been dating Kurt's father and they have decided to live together. Kurt is considered the stereotypical gay boy who is into fashion and has a socalled effeminate behavior. After realizing that he will have to share a room with Kurt in their new house, Finn instantly affirms that he is not 
"cool with that". In a way, Finn reproduces discourses that are similar to the ones that other people use to discriminate against him.

Bearing this in mind, I would like to argue that Glee seems to make use of a subtext which performs what Linda Hutcheon (1989) calls complicitous critique. According to the author, even though we cannot locate ourselves outside ideology, we can reclaim "the right to contest the power of a dominant one, even if from a compromised position" (HUTCHEON, 1989, p. 22). This, for her, is the mark of the postmodern text. In this sense, postmodern complicitous critique implies a double movement, in which certain ideologies are reinscribed and reinforced at the same time that they are contested and criticized. The very concept of agency is aligned with that of complicitous critique: it is not possible to act outside the systems that interpellate us, but we can develop agency from within them. In this sense, the objective here is not solely to demonstrate the ways in which Glee promotes agency, but rather to bring these moments of rupture to the surface so as to contaminate and destabilize the hegemonic forces that are also constitutive of the series.

Finn criticizes Kurt's flamboyant behavior and thus fails to realize that Kurt should not have to blend in, just like he should not have to choose between Glee or football. It seems that the binary notions of gender are so embedded in Finn that he cannot realize that they also function as a form of oppression. Eve Sedgwick (1991) discusses the portrayal of the hegemonic (masculine) versus the repudiated (feminine) gay male. According to her, it is necessary to interrupt "a tradition of assuming that anyone, male or female, who desires a man must by definition be feminine; and that anyone, male or female, who desires a woman must by the same token be masculine". She goes on to say that " $[\mathrm{t}$ ]o begin to theorize gender and sexuality as distinct though intimately entangled axes of analysis has been, indeed, a great advance of recent lesbian and gay thought". However, the author alerts that doing so may still leave the effeminate boy "in the position of the haunting object - this time the haunting object of gay thought itself" (SEDGWICK, 1991, p. 20). In this sense, Finn is not only criticizing Kurt because he is gay, but also because of his so-called femininity. Actually, it is both gayness and its 
effeminate version that are being discriminated against in a misogynist discourse which is also reproduced by masculinist homonormativity.

At the end of the episode, when Kurt is about to be bullied - at this time even physically - while affirming that being different is the best thing about him, Finn appears in the scene wearing a red rubber dress, inspired by a Lady Gaga costume. Despite being mocked at by the other students, Finn explains that he has changed his understanding of Kurt: "I wanna thank you, Kurt. I realize I still have a lot to learn. But the reason I'm here right now in a shower curtain is because of you. And I'm not gonna let anyone lay a hand on you". Finn is not only trying to help Kurt, but he is also showing that he is also queer. Just like Kurt, he dresses a Lady Gaga costume in front of the whole school, implying that he should not have to conform to normativity. He recognizes, then, that Kurt does not need to "blend in" in order to look like everybody else. At the same time, Finn's action and his speech can be considered patronizing - in this sense, Finn seems to work as a kind of hero who has to save Kurt, the "victim". Besides, after Finn's appearance all the Glee club members join Finn and Kurt in their costumes, outnumbering the students who were bullying Kurt, who then leave the scene. In this sense, the other students join the masculine body that Finn represents, whereas they had never joined the effeminate one represented by Kurt. The narrative seems to suggest that it is possible to wear a Lady Gaga-like costume as long as masculinity is not lost. After all, even though Finn wears the costume, his character continues being portrayed as very masculine throughout the series.

There is, in this sense, a narrative resolution at the end of the episode which seems to confirm the subtext of complicitous critique mentioned earlier. At this point, it is as if everything could be solved with one simple act. If we consider the relative unity of the episodes, we will observe that there is a tendency for solution and closure, as if the characters had gone through an "awakening" moment. At the same time, however, if we take into consideration the total unity of the episodes, we will see that Finn is in a process of constant struggle and re-evaluation of his own actions. Moreover, Finn has to repeatedly act - even discursively 
- in order to re-signify certain identity claims. Such is the case of the term "loser": it is through performativity that the characters try to attribute new significance to the concept which is usually pejorative. As we have seen, it is through reiteration that it is possible to produce performative effects and, consequently, promote agency. However, because agency is not guaranteed by (or a direct result of) performativity, the latter can also work to foreclose agency, such as in the case of the Kurt/Finn dynamics. As we have seen, some instances of the show exemplify how the reiteration of essentialist discourses work against the project of promoting agency.

Finn's realization that his oppression is in some ways related to Kurt's can be seen as an example of "solidarity across differences" (HAMES-GARCÍA, 2000, p. 120). Drawing on Maria C. Lugones, Michael R. Hames-García (2000) explains that it is important to understand how different kinds of oppression are interrelated and should, therefore, be part of a common project of resistance. Like Sánchez, Alcoff and Mohanty, the author has a realist understanding of identity, in which "the expansion of the self can only take place once we allow that groups constitute one another in such a way that their constitution is forever altered, enriched, and expanded" (HAMES-GARCÍA, p. 126).

The Glee club seems to function as a kind of consciousnessraising group, in which its members, united through their differences, are able to reflect about their social location and reinterpret their own experiences. They are able not only to reconsider their identities, but also to construct new meanings to their experiences. This seems to be the case of Finn, for whom joining the Glee club serves as a movement towards transformation. Finn's decision of being part of Glee can be compared to the act of coming out, in which occurs "the development of a new identity based on a reinterpretation of experiences" (WILDERSON, 2000, p. 266). In this sense, "this new identity reflects a new and more accurate understanding of who one is in the world and how one can act in the world" (WILKERSON, 2000, p. 266). In other words, it is exactly this possibility of making sense of one's experiences that potentializes Finn's agency (and probably other characters' as well). 
However, Glee presents a more complex dynamic of simultaneous oppression and resistance. For instance, the fact that Finn is usually paired up with Rachel in his performances deserves some attention. Finn and Rachel are, in a certain way, representative of the heterosexual love duet which is considered as part of the musical theatre formula in the United States. Stacy Wolf (2008, p. 9) explains that "the ideological project [...] in the mid-twentieth century was to use the heterosexual couple's journey from enemies to lovers to stand in for the unification of problematic differences in American culture". Not only are Finn and Rachel the typical heterosexual couple, but they can also be considered the main characters in the series. After all, their storylines are usually more developed and make use of more screen time in the episodes in comparison to the storylines of the other characters.

At the same time, however, despite the fact that there are several instances of love duets involving Finn and Rachel, the experience of being part of Glee for them goes beyond developing a love relationship. It is by being in Glee that Finn is able to reflect about who he is and who he wants to be. Therefore, he is able to act upon his identity in order to construct new experiences. Once again, there seems to be a double movement: on one hand, and to a certain extent, Finn's identity construction reinforces heteronormative structures and, on the other hand, potentializes political agency. This is because some instances of performances by Finn can be understood as defying this notion of the heterosexual duet. One example of that takes place in the episode entitled "Home", in which Kurt sings "A House is not a Home" for the Glee club. In this episode, Finn is still reluctant towards the idea of moving to Kurt's house. Even though Kurt sings by himself in front of the club, his performance is paralleled with scenes in which Finn sings the same song at home. For the audience, this technique emphasizes the two characters' connections. It is as if they were actually singing a duet. Besides, even though the lyrics of the original song can be understood as being about a love relationship, in this context they acquire new significance. The two characters, who inhabit liminal spaces, are singing about their necessity of belonging somewhere: "A house is not a home / When there's no one there to hold you tight". The 
lyrics also seem to refer to the two characters' relationship and how they have many similarities: "And a house is not a home / When the two of us are far apart". At times, then, Finn's performances can be considered queer in the sense that they defy heteronormativity.

\section{Final considerations}

As I have tried to make clear, once the characters join Glee, how their identities are complex, fluid and even contradictory become more visible. It is in this sense that their participation in Glee seems to help destabilize stereotypical notions of identity. Besides, the Glee members live a constant struggle in which they try to find some equilibrium between the internal and the external, that is, their senses of themselves and their public identity. This does not mean, however, "that the self can ever achieve perfect coherence" (ALCOFF, 2000, p. 337). Instead, these teenagers seem to try to overcome the negative effects that the external has over them through expressing their queer identities. Even though Finn is considered a "loser" at school, in the narrative he is empowered, since his identity is not only constructed by the different relations of power that interpellate him, but also - and mainly - by the agency he articulates. However, the characters are also, and simultaneously, mainstreamed within the school environment, reproducing normativity and hierarchy (as much as resistance) among distinct and interlocking layers of identity.

One cannot ignore, in this sense, the ways in which the narrative of the series promotes agency (as in the case of Finn) and, at the same time, is sometimes aligned with hegemonic discourses. The issue of resolution is one example: because the episodes - at least in isolation usually have simplistic solution, the narrative can be seen as romantic, idealistic and, therefore, conservative. At these specific moments, it does not seem to account for the complexities involved in the process of constructing one's identity while being constantly interpellated by social structures. 
Another point that deserves attention is the one of competition. Even though the characters embrace the label of "losers", they are still concerned about succeeding and winning the competitions. Despite the fact that the show is sometimes conscious of its obsession about winning, it is the competitions themselves that motivate the characters and the narrative. After all, even though they recognize that losing is part of the game, they continue trying to succeed.

On the other hand, because the series deals with the complexities of the characters' identities in relation to the social structures that surround them. it goes against the idea of positivist thinking, which "insists that success depends upon only working hard" (HALBERSTAM, 2011, p. 3). It is in this sense that I believe that Finn's characterization can be read as portraying the ways in which the issue of agency is a complex one, showing that neither are we reduced to our social location nor are we totally free agents. As Slavoj Žižek (2000, p. 95) puts it, "there is no direct, 'natural' correlation between an agent's social position and its tasks in the political struggle". All in all, Finn's identity construction seems to demonstrate how Glee can be considered an example of postmodern contingency while being inserted simultaneously within restraining hegemonic discourse.

\section{References}

ALCOFF, Linda Martín. “Who's Afraid of Identity Politics?”. In: MOYA, Paula M.L. and HAMES-GARCÍA, Michael R. Reclaiming Identity: Realist Theory and the Predicament of Postmodernism. Berkeley and Los Angeles: BUP, 2000, p. 312-344.

ALCOFF, Linda Martín, and MOHANTY, Satya P. "Reconsidering Identity Politics: an Introduction". Alcoff, Linda Martín, Michael Hames- García, Satya P. Mohanty, and Paula M. L. Moya. Identity Politics Reconsidered. New York: Palgrave Macmillan, 2006, p. 1-9.

BHABHA, Homi K. The Location of Culture. New York: Routledge, 1994. 
BUTLER, Judith. Gender Trouble: Feminism and the Subversion of Identity. 1990. 10th anniversary edition. London: Routledge, 1999.

CRENSHAW, Kimberle. "Mapping the Margins: Intersectionality, Identity Politics, and Violence Against Women of Color". Stanford Law Review. 43: p. 1241-1299, 1991.

FRIEDMAN, Susan S. Locational Feminism: Gender, Cultural Geographies, and Geopolitical Literacy.

<http://www.women.it/cyberarchive/files/stanford.htm>

GELLES, Barrie. "Glee and the Ghosting of the Musical Theatre Canon". Popular Entertainment Studies 2.2: p. 89-111, 2011.

HALBERSTAM, Judith. The Queer Art of Failure. Durham: Duke University Press. 2011

HAMES-GARCÍA, Michael R. "Who Are Our Own People? Challenges for a Theory of Social Identity". Moya, Paula M.L. and Michael R. Hames-García. Reclaiming Identity: Realist Theory and the Predicament of Postmodernism. Berkeley and Los Angeles: BUP, p. 102-129, 2000.

HUTCHEON, Linda. The Politics of Postmodernism. New York: Routledge, 1989.

JOHAL, Gurpreet Singh. "Order in K.O.S". Dei, George, and Johal Gurpreet. Critical Issues in Anti-Racist Research Methodologies. New York: Peter. Lang Publishing Inc, p. 269-288, 2005.

LOXLEY, James. Performativity. New York: Routledge, 2006.

MOYA, Paula M. L. 'Postmodernism, 'Realism', and the Politics of Identity: Cherríe Moraga and Chicana Feminism". MOYA, Paula M.L. and HAMESGARCÍA, Michael R. Reclaiming Identity: Realist Theory and the Predicament of Postmodernism. Berkeley and Los Angeles: BUP, p. 67-101, 2000.

MURPHY, Ryan. Glee. DVD-ROM. Twentieth Century Fox Film Corporation, 2009-2010. 
SÁNCHEZ, Rosaura. "On a Critical Realist Theory of Identity”. ALCOFF, Linda Martín, HAMES-GARCÍA, Michael, MOHANTY, Satya P., and MOYA Paula M. L. Identity Politics Reconsidered. New York: Palgrave Macmillan, p. 31-52, 2006.

SEDGWICK, Eve K. “How to Bring Your Kids Up Gay”. Social Text 29: p. 18-27, 1991.

SILVA, Leonardo da. "A Loser Like Me": Identity and Agency in Ryan Murphy's Glee. Unpublished Master's Thesis. Programa de Pós-Graduação em Inglês: Estudos Linguísticos e Literários. Florianópolis: Universidade Federal de Santa Catarina (UFSC), 2014.

WEBB, Jen. Understanding Representation. London: SAGE Publications Inc, 2009.

WILKERSON, William S. (2000). "Is There Something You Need to Tell Me? Coming out and the Ambiguity of Experience", 2000.

MOYA, Paula M.L. and HAMES-GARCÍA, Michael R Reclaiming Identity: Realist Theory and the Predicament of Postmodernism. Berkeley and Los Angeles: BUP, p. 251-278, 2000.

WOLF, Stacy. "Defying Gravity: Queer Conventions in the MusicalWicked". Theatre Journal60.1: 1.21, 2008.

ZIZEK, Slavoj. “Class Struggle or Postmodernism?”. BUTLER, Judith, LACLAU, Ernesto and ZIZEK, Slavoj. Contingency, Hegemony, Universality: Contemporary Dialogues on the Left. London. Verso, p. 90-130, 2000.

Recebido em 31 de julho de 2020.

Aceito em 30 de outubro de 2020. 